\title{
Fabio Vasarri, Chateaubriand e la gravità del comico
}

\section{Alessandra Marangoni}

\section{(2) OpenEdition}

\section{Journals}

\section{Edizione digitale}

URL: http://journals.openedition.org/studifrancesi/6675

DOI: ERREUR PDO dans /localdata/www-bin/Core/Core/Db/Db.class.php L.34 : SQLSTATE[HY000]

[2006] MySQL server has gone away

ISSN: 2421-5856

\section{Editore}

Rosenberg \& Sellier

\section{Edizione cartacea}

Data di pubblicazione: 1 septembre 2010

Paginazione: 380-381

ISSN: 0039-2944

\section{Notizia bibliografica digitale}

Alessandra Marangoni, «Fabio Vasarri, Chateaubriand e la gravità del comico», Studi Francesi [Online], 161 (LIV | II) | 2010, online dal 30 novembre 2015, consultato il 08 janvier 2021. URL: http:// journals.openedition.org/studifrancesi/6675 ; DOI: https://doi.org/10.4000/studifrancesi.6675

Questo documento è stato generato automaticamente il 8 janvier 2021.

\section{(c) (i) (9)}

Studi Francesi è distribuita con Licenza Creative Commons Attribuzione - Non commerciale - Non opere derivate 4.0 Internazionale. 


\title{
Fabio Vasarri, Chateaubriand e la gravità del comico
}

\author{
Alessandra Marangoni
}

\section{NOTIZIA}

FABIO VASARRI, Chateaubriand e la gravità del comico, Taranto, Lisi, 2009, «Quaderni del

Seminario di Filologia Francese», pp. 224.

1 L'opera di Chateaubriand viene guardata da un'angolatura insolita: quella del comico, quella tonalità che Proust e tanti altri dopo di lui non riconoscevano come facente parte dello stile dell'Enchanteur. Insomma, un intero libro per far evadere Chateaubriand dal ritratto del lirico dolente. Emergono varie facce del registro comico: una di stampo classicistico, una all'insegna della mescolanza romantica, una ancor più moderna ed esorbitante.

2 Il primo capitolo («Il discorso») deve fare i conti con le molte dichiarazioni dell'autore circa il carattere inferiore e subordinato del comico (le note frecciate nei confronti dell'ironia voltairiana), ma evidenzia anche importanti spunti sulla funzione di contrappunto dello stile comico, sulla distinzione tra un comico basso (da evitare, almeno in teoria) e un comico alto (il migliore Molière), sull'affacciarsi di un modello anglosassone, imperniato sul mélange shakespeariano.

3 Il secondo capitolo («I giorni») si appunta a definire il riso di Chateaubriand, in base a testimonianze di persone a lui prossime: Sainte-Beuve, Joubert, Hugo, Molé, il segretario Marcellus, senza tralasciare la corrispondenza privata. La sfida è naturalmente quella di scalfire l'immagine cupa e accigliata di un eterno René incapace di ridere, portando a galla brevi sprazzi di riso sfrenato.

4 Il terzo e ultimo capitolo («Le forme») contiene un'analisi puntuale delle molte gradazioni che può assumere lo stile comico in mano al maestro della liricità. Un comico leggero, di carattere e di situazione, che si traduce in scene e ritratti, fondato sull'implicita superiorità del soggetto sull'oggetto del riso. Il modo eroicomico 
dell'innalzamento del triviale. Un'autoironia per lo più non realmente degradante. Una diffusa pratica della mescolanza che unisce comicità e gravità, con esiti talora imprevedibili che vanno nella direzione di un comico basso-di ascendenza rabelaisiana-legato al corpo e alla confusione babelica delle lingue. Fino a poter scorgere tracce di un moderno umorismo nero, fino a dover dire, a un certo punto: «sembra di leggere une pagina di Lautréamont». Questo comico meno facilmente classificabile, in cui anche l'autoironia sconfina nell'umorismo, viene infine visto nella contiguità di riso e morte. Tutto questo senza mai dimenticare i grandi saggi teorici sull'argomento (Baudelaire, Bergson, Freud, Pirandello, Propp...), né l'opzione cristiana dell'autore, né la complessa stratificazione testuale (per le molte riprese e revisioni) delle sue opere. 